\title{
Implikasi Pembatalan Akta Berita Acara Rapat Umum Pemegang Saham Tentang Hibah Saham
}

\section{Clara Venesia Inma}

Magister Kenotariatan Fakultas Hukum Universitas Islam Indonesia Yogyakarta Indonesia Jln. Cik Di Tiro No. 1 Yogyakarta Indonesia venesiaclara@gmail.com

Key Word: Abstract

Deed Cancellation, This study examines the implications of the cancellation of the deed of minute of the Notary, Share Grant GMS on Share Grants. The formulation of the problem in this research is first, how is the notary's responsibility for deed of minute of the GMS on share grant made before them which is cancelled by the court and second, what is the legal solution for the notary on the deed of minute of the GMS on share grant made before them which is canceled by the court. This is a normative legal research which is supported by information from source persons. The approaches used in this research are the Statutory, Case, and Conceptual approaches. The method used is literature study in the form of primary, secondary and tertiary legal materials. The analysis was carried out qualitatively. The results of the study conclude that first, the notary is not directly responsible for deed of minute of the GMS on share grant made before them which is canceled by the court. The notary's responsibility here is to return to its original state, hence they must make a statement based on the court decision. Second, the legal solution for the notary is that they must submit to the court's decision which with the cancellation of the deed of minute by the court, the notary returns the situation to its original state by holding an Extraordinary GMS again with the shareholders. Suggestions in this study are notaries in carrying out their duties and positions must be guided by the existing laws and regulations. Notaries must act more carefully and carefully in carrying out a legal act

Kata-kata Kunci:
Notaris,
Pembatalan Akta,
Hibah Saham

\section{Abstrak}

Penelitian ini meneliti tentang implikasi pembatalan akta berita acara RUPS Hibah Saham

Tentang Hibah Saham. Rumusan masalah dalam penelitian ini pertama, bagaimana tanggung jawab notaris terhadap akta berita acara RUPS tentang hibah saham yang dibuat dihadapannya yang dibatalkan oleh pengadilan dan kedua, apa solusi hukum bagi notaris atas akta berita acara RUPS tentang hibah saham yang dibuat dihadapannya dibatalkan oleh pengadilan. Penelitian merupakan penelitan normatif yang didukung oleh keterangan dari narasumber. Pendekatan yang digunakan dalam penelitian ini adalah pendekatan Perundang-Undangan, Kasus, dan Konseptual. Metode yang digunakan adalah studi kepustakaan berupa bahan hukum primer, sekunder dan tersier. Analisa dilakukan secara kualitatif. Hasil penelitian menyimpulkan bahwa pertama, notaris tidak secara langsung bertanggung jawab terhadap akta berita acara RUPS tentang hibah saham yang dibuat dihadapannya yang dibatalkan oleh pengadilan. Tanggung jawab notaris disini yaitu adanya kembali ke keadaan semula maka harus membuat surat pernyataan berdasarkan dari putusan pengadilan. Kedua, solusi hukum bagi notaris adalah bahwa notaris harus tunduk pada putusan pengadilan yang mana dengan dibatalkannya akta tersebut oleh pengadilan maka notaris mengembalikan keadaan seperti semula dengan melakukan RUPS Luar Biasa kembali dengan para pemegang saham. Saran dalam penelitian ini adalah notaris dalam menjalankan tugas dan jabatannya harus berpedoman pada peraturan perundang-undangan yang ada. Notaris harus bertindak lebih hati-hati dan cermat dalam melakukan suatu perbuatan hukum 


\section{Pendahuluan}

Perkembangan perekonomian di Indonesia pada saat ini semakin berkembang yang nyatanya banyak subjek-subjek hukum yang melakukan aktivitas perbuatan hukum salah satunya perseroan terbatas secara tegas yang diakui oleh hukum sebagai badan hukum dan sebagai subjek hukum yang cakap melakukan perbuatan hukum atau mengadakan hubungan hukum dengan berbagai pihak layaknya manusia. ${ }^{1}$

Perseroan terbatas memiliki ciri khas yang membedakan subjek hukum pribadi dengan subjek hukum yang berbadan hukum dimana saat lahirnya subjek hukum tersebut, pada subjek hukum pribadi status subjek hukum dianggap telah ada bahkan pada saat orang perseroangan berada dalam kandungan sedangkan badan hukum lahirnya sebagai subjek hukum dilihat dari status badan hukumnya diperoleh setelah ia mendapatkan pengesahan dari pejabat yang berwenang, yang memberikan hak-hak dan kewajiban dan harta kekayaan sendiri bagi badan hukum dan terlepas dari hak-hak, kewajiban dan harta kekayaan pribadi para pendiri, pemegang saham, ataupun pengurusnya. ${ }^{2}$

Notaris sebagai pejabat umum memiliki peran yang penting dalam penegakan hukum di Indonesia, karena seorang notaris mempunyai kuantitas yang besar dan seorang notaris juga dikenal sebagai kelompok elit Indonesia. ${ }^{3}$ Seorang notaris sebagai pejabat umum yang berwenang untuk membuat akta autentik dan memliki kewenangan lainnya sebagaimana telah diatur dalam Undang-Undang Nomor 2 Tahun 2014 tentang Perubahan Atas Undang-Undang Nomor 30 Tahun 2004 tentang Jabatan Notaris.

Biasanya suatu perseroan memerlukan atau memakai jasa dari seorang notaris, keberadaan notaris sangat penting bagi kehidupan masyarakat salah satunya termasuk dalam suatu perseroan, karena notaris memberikan kepastian hukum pada masyarakat yang menyangkut pembuatan akta otentik yang dibuat dihadapan notaris. Dalam hal tersebut dibutuhkan jasa dari seorang notaris sehingga akta tersebut dapat diterima oleh semua pihak yang bersangkutan dan memiliki kepastian hukum. ${ }^{4}$ Khususnya pada perseroan terbatas notaris berperan penting seperti pendirian perusahaan, jual beli saham, serta perubahan anggaran dasar melalui rapat umum pemegang saham.

Maka dari itu pemindahan dilakukan dengan akta pemindahan hak baik dalam otentik maupun akta dibawah tangan, kemudian dalam proses pemindahan saham tersebut, akta pemindahan hak atau salinannta disampaikan secara tertulis kepada perseroan dan direksi wajib mencatat pemindahan hak atas saham tersebut, dalam daftar pemegang saham perseroan dan/daftar khusus dan wajib memberitahukan perubahan tersebut kepada Menteri paling lama 30 hari sejak tanggal pencatatan pemindahan hak yang mana tercantum di dalam Pasal 56 Undang-Undang Nomor 40 Tahun 2007 tentang Perseroan Terbatas.

Bentuk pelanggaran misalnya hibah saham yang tidak sesuai dengan syarat subjektif dan objektif yang tidak cermat oleh notaris, apabila syarat tersebut tidak dapat dipenuhi maka akta yang dibuat oleh notaris dapat batal demi hukum atau dapat

1 Azizah, Hukum Perseroan Terbatas, Intimedia, Malang, 2015, hlm. 2.

2 Ahmad Yani, Seri Hukum Bisnis Perseroan Terbatas, Raja Grafindo, Jakarta, 2000, hlm. 8.

3 Abdul Ghofur Anshori, Lembaga Kenotariatan Indonesia, Perspektif Hukum dan Etika, UII Press, Yogyakarta, 2009, hlm. 1.

${ }^{4}$ R. Subekti, Hukum Pembuktian, Pradnya Paramita, Jakarta, 2001, hlm. 48. 
dibatalkan oleh pengadilan. Kerugian yang dialami oleh pihak-pihak juga dimintai pertanggungjawaban karena terbukti telah melakukan perbuatan melawan hukum. Hal itu diatur di dalam Pasal 1365 KUHPerdata yang menyebutkan bahwa tiap perbuatan melanggar hukum yang membawa kerugian pada orang lain, mewajibkan orang yang karena salahnya menerbitkan kerugian itu, mengganti kerugian tersebut.

Yang melatar belakangi penulis memilih kasus ini untuk dijadikan objek kajian studi kasus hukum dengan alasan yaitu dalam kasus ini terdapat kejanggalan atau cacat hukum dalam tahapan proses peradilan dan juga isi putusannya. Kejanggalan dan cacat hukum itu misalnya terkait dengan hukum formil dan hukum materiil yang tidak diterapkan secara baik dan benar atau bertentangan dengan asas-asas keilmuan hukum serta dianggap bertentangan dengan rasa keadilan masyarakat. Setelah penulis mempelajari secara seksama dari Putusan Pengadilan Nomor: 93/Pdt.G/2017/PN.Lpb, maka penulis tertarik untuk meneliti serta menganalisis putusan tersebut mengenai pembatalan akta berita acara rapat umum pemegang saham tentang hibah saham yaitu, pada intinya di dalam putusan tersebut kasusnya yaitu terdapat terjadinya suatu perbuatan hukum yang dilakukan oleh para pihak yaitu Andy Haryanto sebagai Penggugat, PT. Gunung Selamat Lestari sebagai Tergugat I, Minah Sarsi sebagai Tergugat II, Wendy Haryanto sebagai Tergugat III dan Yanty Sulaiman sebagai Turut Tergugat selaku Notaris. Dimana dalam kasus posisi ini bahwa penggugat adalah pemegang 3.822 helai saham pada PT. Gunung Selamat Lestari sesuai akta Nomor 5 tanggal 3 September 2014 dihadapan Yanty Sulaiman. Serta penggugat pada tangggal 3 September 2014 pernah memberikan Surat Kuasa Nomor 9 kepada tergugat untuk mengeluarkan 3.822 suara dalam Rapat Umum Pemegang saham atau Rapat Umum Pemegang Saham Luar Biasa.

\section{Rumusan Masalah}

Berdasarkan latar belakang tersebut di atas, berikut rumusan masalah yang diangkat: pertama, bagaimana tanggungjawab notaris terhadap akta berita acara rapat umum pemegang saham tentang hibah saham yang dibuat dihadapannya yang dibatalkan oleh pengadilan? Kedua, apa solusi hukum bagi notaris atas akta berita acara rapat umum pemegang saham tentang hibah saham yang dibuat dihadapannya yang dibatalkan oleh pengadilan?

\section{Tujuan Penelitian}

Adapun tujuan dari penelitian ini; pertama, untuk menganalisis tanggungjawab notaris terhadap akta berita acara acara rapat umum pemegang saham tentang hibah saham yang dibuat dihadapannya yang dibatalkan oleh pengadilan. Kedua, untuk menganalisis solusi hukum bagi notaris atas akta berita acara acara rapat umum pemegang saham tentang hibah saham yang dibuat dihadapannya yang dibatalkan oleh pengadilan.

\section{Metode Penelitian}

Pada metode penelitian ini, peneliti memaparkan jenis penelitian yang digunakan normatif, metode pendekatan yang digunakan adalah perundang-undangan, kasus, 
konseptual, sumber data, menggunakan bahan hukum primer, sekunder dan tersier, cara pengambilan data dalam penelitian ini guna untuk memperoleh bahan hukum yang diperlukan, maka digunakan teknik pengumpulan bahan hukum tersebut dengan penelitian kepustakaan, dan didukung oleh wawancara kepada narasumber, dan juga teknik analisis data dengan menggunakan metode deskriptif kualitatif dengan bahan hukum yang diperoleh dari studi putusan Pengadilan, diperpustakaan disusun secara sistematis berdasarkan objek permasalahan.

\section{Hasil Penelitian dan Pembahasan}

Di dalam kasus putusan pengadilan Nomor: 93/Pdt.G/2017/PN.Lbp ini terjadinya suatu perbuatan hukum yang dilakukan oleh para pihak yaitu Andy Haryanto sebagai Penggugat, dengan PT. Gunung Selamat Lestari sebagai Tergugat I, Minah Sarsi sebagai Tergugat II, Wendy Haryanto sebagai Tergugat III dan Yanty Sulaiman sebagai Turut Tergugat selaku Notaris.

Yang mana penggugat adalah pemegang 3.822 helai saham pada PT. Gunung Selamat Lestari yang tertuang dalam Akta Notaris No. 5 tanggal 3 September 2014 dihadapan Yanti Sulaiman selaku Turut Tergugat. Dan pada saat itu juga penggugat telah memberikan Surat Kuasa Nomor 9 tertanggal 3 September 2014 kepada Tergugat II yaitu saudara Minah Sarsi untuk mengelolah 3.822 suara dalam Rapat Umum Pemegang Saham Luar Biasa.

Pada 13 Februari 2015 penggugat pernah membuat dan mengirimkan surat pencabutan Kuasa atas Surat Kuasa Nomor 9 tertanggal 3 September 2014 kepada tergugat II dan telah ditembuskan kepada Tergugat I dan Tergugat III.

Kemudian pada 20 Januari 2016 bahwa Tergugat I menyelenggarakan Rapat Umum Pemegang Saham Luar Biasa tanpa sepengetahuan Penggugat, yang dihadiri oleh Tergugat II dan Tergugat III, yang mana Tergugat II ini menggunakan Surat Kuasa Nomor 9 tertanggal 3 September 2014 tersebut untuk mewakili penggugat sebagai pemilik saham sebanyak 3.822 lembar saham pada PT. Gunung Selamat Lestari, dan telah menghibahkan seluruh saham Penggugat kepada Tergugat II. Hasil daripada Rapat Umum Pemegang Saham tersebut tertera dalam Akta Notaris Nomor 10 tentang "Berita Acara Rapat" dan Akta Notaris Nomor 11 tentang "Hibah Saham" masing-masing tertanggal 20 Januari 2016 dihadapan Turut Tergugat.

Seperti dalam kasus putusan yang penulis teliti di atas yaitu dalam suatu Perseroan Terbatas bahwa terdapat para pihak yang melakukan suatu perbuatan hukum yang mana Penggugat adalah sebagai pemegang saham pada PT. Gunung Selamat Lestari sesuai dengan Akta No. 5 yang dibuat dihadapan Notaris dan Penggugat memberikan Surat Kuasa kepada Tergugat untuk mengeluarkan suara dalam Rapat Umum Pemegang Saham, disini berarti adanya kesepakatan antara para pihak atas perjanjian yang ada didalam akta tersebut. Dalam hal ini Penggugat adalah sebagai pemberi kuasa kepada Tergugat II yang penerima kuasa, yang mana dasar dari hubungan hukum ini dalam Pasal 1792 KUHPerdata menyebutkan perihal hakekat dari suatu pemberian kuasa adalah suatu persetujuan dengan mana seorang memberikan kekuasaan kepada orang lain dimana orang yang diberi kuasa tersebut menyelenggarakan suatu urusan untuk 
dan atas nama pemberi kuasa. Pemberian kuasa merupakan suatu perjanjian yang mana seorang memberikan kuasa atau wewenang kepada seorang lain yang menerimanya untuk menyelenggarakan suatu urusan perbuatan hukum.

Kuasa dapat diberikan dan diterima dalam suatu akte umum, dalam suatu tulisan dibawah tangan, bahkan dalam sepucuk surat ataupun dengan lisan. Penerimaan suatu kuasa dapat pula terjadi secara diam-diam dan disimpulkan dari pelaksanaan kuasa itu oleh si kuasa. Dari ketentuan tersebut dapat dilihat bahwa pemberian kuasa itu adalah bebas dari suatu bentuk cara formalitas tertentu dengan perkataan lain adalah suatu perjanjian konsensual artinya sudah mengikat sah pada detik tercapainya sepakat antara si pemberi dan si penerima kuasa. ${ }^{5}$

Yang menyangkut tentang akta hibah saham itu adalah setelah mendapat persetujuan dari Rapat Umum Pemegang Saham (RUPS), itu merupakan suatu asesor untuk melakukan perbuatan hukum hibah saham, maknanya dari hibah saham ini yaitu si pemberi hibah itu pada saat masih hidup, boleh diberika kepada siapa saja, sebab daripada itu untuk mengalihkan suatu saham itu harus mendapatkan persetujuan dari pemegang saham.

Dalam hal ini dengan digunakannya surat kuasa No. 9 oleh Tergugat II pada saat Rapat Umum Pemegang Saham Luar Biasa tersebut padahal telah adanya surat pencabutan kuasa maka Tergugat I, II, III telah melakukan perbuatan melawan hukum. Berdasarkan Pasal 1365 KUHPerdata menyebutkan setiap perbuatan melawan hukum yang menimbulkan kerugian terhadap orang lain, mewajibkan kepada orang itu karena kesalahannya untuk mengganti kerugian tersebut. Artinya bahwa para pihak tidak cakap hukum dan kewenangan bertindak dalam melakukan suatu perbuatan hukum, dimana pada Pasal 39 ayat (1) UU No. 30 Tahun 2004 tentang Jabatan Notaris menentukan bahwa para penghadap harus memenuhi syarat paling sedikit berumur 18 tahun atau telah menikah, dan cakap melakukan perbuatan hukum.

Berkaitan dengan Undang-Undang No. 40 Tahun 2007 Tentang Perseroan Terbatas mengenai kehadiran pemegang saham dapat dilihat dan diperhitungkan dari kehadiran diri sendiri pemegang saham yang bersangkutan, ataupun jika dihadiri oleh pihak lain berdasarkan surat kuasa. Jadi apabila salah satu diantara mereka hadir maka pemegang saham yang bersangkutan dianggap hadir dalam RUPS dan diperhitungkan dalam kuorum RUPS sesuai dengan Pasal 85 Undang-Undang Perseroan Terbatas yaitu: "pemegang saham baik, baik sendiri maupun diwakili berdasarkan surat kuasa berhak menghadiri RUPS dan menggunakan hak suaranya sesuai dengan jumlah saham yang dimilikinya".

Pemegang saham juga dapat memberikan kuasa kepada anggota direksi, anggota dewan komisaris atau karyawan perseroan untuk mewakili dirinya dalam RUPS, pada dasarnya pemegang saham dapat memberikan kuasa kepada siapa saja untuk mewakili dalam RUPS. ${ }^{6}$ Akan tetapi dalam hal pemegang saham memberikan kuasanya tersebut, suara tersebut tidak ikut dihitung dalam pemungutan suara terdapat dalam Pasal 85 ayat (4) Undang-Undang Perseroan Terbatas yaitu: "Dalam menetapkan kuorum RUPS,

\footnotetext{
${ }^{5}$ R. Subekti, Aneka Perjanjian, PT.Citra Aditya Bakti, Bandung, 2014, hlm. 141.

${ }^{6}$ Pasal 85 ayat (1) Undang-Undang No. 40 Tahun 2007.
} 
saham dari pemegang saham yang diwakili anggota Direksi, anggota Dewan Komisaris, dan karyawan Perseroan sebagai kuasa ikut dihitung, tetapi dalam pemungutan suara mereka sebagai kuasa pemegang saham tidak berhak mengeluarkan suara". Namun apabila dalam RUPS baik pemegang saham yang bersangkutan dan kuasanya hadir, maka surat kuasa yang diberikan kepada kuasanya menjadi tidak berlaku.

Berdasarkan dari kasus tersebut penulis membahas dari rumusan masalah yaitu tanggungjawab notaris terhadap akta yang dibuatnya yang dibatalkan oleh pengadilan, dapat dikatakan bahwa akta yang dibuat oleh notaris berkaitan dengan suatu perikatan yang dibuat oleh para pihak. Sifat yang ada dari hukum perikatan khususnya yang lahir karena perjanjian, bahwa undang-undang hanya mungkin dan boleh diubah atau dinyatakan tidak berlaku oleh mereka yang membuatnya, artinya kesepakatan para pihak yang dituangkan dalam akta otentik mengikat kedua belah pihak sebagaimana mengikatnya undang-undang. Jadi notaris tidak secara langsung bertanggungjawab atas pembatalan akta tersebut karena akta tersebut dikehendaki oleh para pihak yang menghadapnya, melainkan kepada para piha yang melakukan perikatan tersebut.

Kemudian solusi hukum terhadap akta yang dibuatnya yang dibatalkan oleh pengadilan adalah tindakan yang dilakukan oleh yang tak cakap dan tidak wenang adanya kebatalan dan pembatalan akta, disini kepada Turut Tergugat untuk membatalkan Akta Notaris No. 10 tentang Berita Acara Rapat dan Akta Notaris No. 11 tentang Hibah Saham, dan meminta mengembalikan kedudukan Penggugat seperti semula yaitu sebagai pemegang saham. Karena yang menyangkut pembatalan juga harus dilakukan melalui Rapat Umum Pemegang Saham (RUPS) yang dinamakan dengan RUPS Luar Biasa, karena RUPS Luar Biasa merupakan semua perbuatan hukum yang dilakukan oleh Perseroan Terbatas ataupun direksi boleh melakukan RUPS Luar Biasa kapan saja tetapi harus dihadiri oleh pemegang saham apa yang sudah dilakukan sesuai dengan anggaran dasarnya, itu menyangkut pembatalan berita acara, jika tidak melalui RUPS maka tidak bisa. Serta kehati-hatian para penghadap dan notaris, agar hati-hati dalam melakukan perbuatan hukum sesuai dengan peraturan perundang-undangan yang berlaku.

\section{Penutup}

\section{Kesimpulan}

Berdasarkan hasil penelitian ini dapat disimpulkan terkait rumusan masalah dalam penelitian ini yaitu sebagai berikut:

1. Tanggungjawab notaris terhadap akta berita acara rapat umum pemegang saham tentang hibah saham yang dibuat dihadapannya yang dinyatakan batal dan tidak berkekuatan hukum oleh pengadilan adalah bahwa notaris tidak secara langsung bertanggungjawab atas pembatalan akta tersebut karena tugas notaris hanya membuat akta yang dikehendaki oleh para pihak yang menghadapnya, serta notaris berkewajiban memberikan penjelasan kepada para penghadap agar tindakan yang dituangkan dalam akta sesuai dengan hukum yang berlaku. Tetapi dibatalkannya akta tersebut oleh pengadilan karena hal tersebut masuk dalam ranah perdata maka hakim mengadili perkara kepada para pihak yang melakukan perikatan tersebut. Dengan 
demikian tanggungjawab dari seorang notaris disini adanya kembali ke keadaan yang semula maka harus membuat surat pernyataan tetapi berdasarkan dari putusan pengadilan.

2. Solusi hukum bagi notaris atas akta berita acara rapat umum pemegang saham tentang hibah saham yang dibuat dihadapannya yang dibatalkan oleh pengadilan adalah bahwa notaris harus tunduk pada putusan pengadilan, akta tersebut merupakan suatu produk yang dibuat oleh notaris tetapi dibatalkan oleh pengadilan, berarti dalam hal ini harus dikembalikan seperti semula dari akta-akta yang dibuat dihadapan notaris dengan mengembalikan hak-hak dari penggugat sebagai pemilik saham, yang mana dengan dibatalkannya akta tersebut oleh pengadilan maka notaris mengembalikan keadaan seperti semula yang ada dengan melakukan RUPS Luar Biasa kembali dengan para pemegang saham.

\section{Saran}

Berdasarkan kesimpulan di atas, maka saran yang diberikan oleh penulis adalah sebagai berikut:

1. Seorang notaris dalam menjalankan tugas dan jabatannya harus berpedoman pada peraturan perundang-undangan yang ada. Mengingat seorang notaris sebagai pejabat umum yang mempunyai peran penting dalam pembuatan suatu akta yang merupakan suatu alat bukti yang sempuna untuk menjamin kebenaran dari pernyataan para pihak yang menghadapnya, sebaliknya jika notaris meminta buktibukti lainnya sehingga kebenaran akta tersebut dapat dibuktikan di pengadilan.

2. Untuk menghindari terjadinya kerugian kepada pihak lain terhadap akta tersebut, notaris ataupun masyarakat wajib harus bertindak lebih hati-hati dan cermat dalam melakukan suatu perbuatan hukum karena pembuatan akta dimaksud untuk memberikan bukti bagi perbuatan hukum yang dilakukan oleh para pihak.

\section{Daftar Pustaka}

\section{Buku}

Abdul Ghofur Anshori, Lembaga Kenotariatan Indonesia, Perspektif Hukum dan Etika, UII Press, Yogyakarta, 2009.

Azizah, Hukum Perseroan Terbatas, Intimedia, Malang, 2015.

R. Subekti, Hukum Pembuktian, Pradnya Paramita, Jakarta 2001. Aneka Perjanjian, PT.Citra Aditya Bakti, Bandung, 2014.

Yani, Ahmad, Seri hukum Bisnis Perseroan Terbatas, Raja Grafindo, Jakarta, 2000.

\section{Peraturan Perundang-Undangan}

Undang-Undang Nomor 40 Tahun 2007 tentang Perseroan Terbatas

Undang-Undang Nomor 2 Tahun 2014 tentang Jabatan Notaris 